\title{
PEND OREILLE WETLANDS WILDLIFE MITIGATION PROJECT MANAGEMENT PLAN FOR THE "DILLING ADDITION"
}

\author{
Prepared by: \\ Ray D. Entz \\ Kalispel Natural Resource Department
}

\author{
Prepared for: \\ U.S. Department of Energy \\ Bonneville Power Administration \\ Environment, Fish and Wildlife \\ PO Box 3621 \\ Portland, Oregon 97208
}

Project No. 91-060-00

Contract No. 93BI62041

January 15, 1999 


\section{TABLE OF CONTENTS}

\subsection{INTRODUCTION}

\subsection{PROJECT DESCRIPTION}

2.1 Scope of Project

2.2 Objectives

2.3 Workplan

\subsection{METHODS}

3.1 General

3.2 Habitat Evaluation Procedure

\subsection{RESULTS}

\subsection{DISCUSSION}

5.1 Implementation

5.2 Budget

\subsection{LITERATURE CITED}

\subsection{APPENDICES}

A. Habitat evaluation procedures (HEP) for the "Dilling Addition."

\section{LIST OF FIGURES}

Figure 1. General location of "Dilling Addition" Mitigation Project including HEP site locations ........................................................................................ 5

Figure 2. Wetlands information map of the "Dilling Addition" ............................. 12

\section{LIST OF TABLES}

Table 1. Habitat Unit losses for Albeni Falls Dam .............................................. 1

Table 2. Albeni Falls Dam baseline habitat units (HU) credited to the project and projected HU's with management ......................................................... 2

Table 3. Forest inventory data for the "Dilling Addition" and adjacent U. S. Forest Service lands as the model comparison..................................................... 6

Table 4. Timber volumes for the mixed deciduous forest habitat ............................ 6

Table 5. Fish species abundance and composition for Campbell's Slough............... 7

Table 6. Objectives and costs for out year funding of the project ........................... 15 


\subsection{INTRODUCTION}

This report is a recommendation from the Kalispel Tribe to the Bonneville Power Administration (BPA) and the Columbia Basin Fish and Wildlife Authority (CBFWA) for management of the Pend Oreille Wetland Wildlife Mitigation project II (Dilling Addition) for the extensive habitat losses caused by Albeni Falls Dam on Kalispel Ceded Lands.

Albeni Falls Dam is located on the Pend Oreille River near the Washington-Idaho border, about 25 miles upstream of the Kalispel Indian Reservation. The dam controls the water level on Lake Pend Oreille. The lake was formerly the center of subsistence use by the Kalispel Tribe. Flooding of wetlands, and water fluctuations both on the lake and downstream on the river, has had adverse impacts to wildlife and wildlife habitat.

An extensive process was followed to formulate and prioritize wildlife resource goals. The Kalispel Natural Resource Department provided guidance in terms of opportunities onsite. To prioritize specific goals, the Albeni Falls Interagency Work Group and the Columbia Basin Fish and Wildlife Authority Wildlife Caucus were consulted. From this process, the top priority goal for the Kalispel Tribe is: Protect and develop riparian forest and shrub, and freshwater wetlands, to mitigate losses resulting from reservoir inundation and river level fluctuations due to Albeni Falls Dam. Indicator species used to determine the initial construction/inundation loses and mitigation project gains include Bald Eagle (breeding and wintering), Black-capped Chickadee, Canada Goose, Mallard, muskrat, white-tailed deer, and Yellow Warbler.

\subsection{PROJECT DESCRIPTION}

\subsection{Mitigation History}

The construction of Albeni Falls Dam in 1951 inundated 6,617 acres of wetlands once used by the Kalispel Indian Tribe. In addition, fluctuations in water levels both above and below the dam, destroyed riparian habitat and precluded the re-establishment of riparian plant communities. Finally, habitat loss occurred 40 years ago and cumulative wildlife losses have been extensive (Table 1). These factors resulted in both direct and indirect losses of wildlife and associated habitats.

Table 1. Habitat losses by target species for Albeni Falls Dam.

\begin{tabular}{lcc} 
Target Species & & Total Habitat Units \\
\cline { 1 - 1 } Bald Eagle - wintering & & 4365 \\
Bald Eagle - breeding & & 4508 \\
Black-capped Chickadee & & 2286 \\
Canada Goose & & 4699 \\
Mallard & & 5985 \\
Muskrat & 1756 \\
Redhead - wintering & & 3379 \\
White-tailed deer & & 1680 \\
Yellow Warbler & $\mathbf{( 7 1 )}$ \\
Total & & $\mathbf{2 8 , 5 8 7}$
\end{tabular}


Restoration and enhancement of the 164-acre floodplain site directly adjacent to the Pend Oreille River, "Flying Goose Ranch", and Kalispel Indian Reservation is the basis of this proposal. The land has been purchased by the Kalispel Tribe (with BPA funds) and is held as fee-title property (presently seeking a transfer of the property into trust with the BIA for the Tribe). The project is to be incorporated in the Ranch management and budget of the "Flying Goose Ranch." There will be no net increase in financial need, as it will be included in Pend Oreille Wetlands (Flying Goose Ranch) budget. This course of action will secure the site and improve wildlife habitat on the project site.

\subsection{Mitigation Objective}

Purchase and eventual transfer of title will protect 225.0 HU's of mallard, Canada goose, Bald Eagle, White-tailed deer, Muskrat and riparian dependent passerine birds such as Black-capped Chickadee and Yellow Warbler (Appendix A). Habitat enhancement and restoration will account for an additional 75 to $150 \mathrm{HU}$ 's (Table 2).

Table 2. Baseline HU's and projected HU's with management.

\begin{tabular}{lcccc} 
Target Species & $\begin{array}{c}\text { Baseline Habitat } \\
\text { Units }\end{array}$ & $\begin{array}{c}\text { Projected HU's } \\
\text { with Enhancements }\end{array}$ & $\begin{array}{c}\text { Acreage } \\
\text { Changes }\end{array}$ \\
\cline { 1 - 2 } \cline { 5 - 5 } Bald Eagle - wintering & & 48.4 & 58 & +10 \\
Bald Eagle - breeding & & 51 & 60 & +10 \\
Black-capped Chickadee & & 21.3 & 35 & +10 \\
Canada Goose & 37.3 & 33 & -5 \\
Mallard & 53 & 69 & -20 \\
Muskrat & 6.2 & 22 & - \\
Redhead - wintering & - & - & - \\
White-tailed deer & 7.9 & 22 & +10 \\
Yellow Warbler & 8.7 & 21 & +10 \\
Total & 233.8 & 320 & -
\end{tabular}

\subsection{GENERAL SITE DESCRIPTION}

The Kalispel Indian Reservation is in Pend Oreille County in northeast Washington State. The project area is in the valley of the Pend Oreille River and adjacent to the river. The river is large, averaging $25,000 \mathrm{cfs}$ annually, with spring peak average of 90,000 cfs. The Selkirk Mountains rise 6000-7000 ft above mean sea level on both sides of the valley.

The valley floor is well developed from river alluvium. Wetlands are well distributed in these rich deposits. Most of the valley floor is considered to be, or to have once been wetland by Eastern Washington University Geography Department classification and National Wetlands Inventory maps. The combination of wetlands, river, and north-south aligned mountains has resulted in an important migratory flyway for waterfowl and Bald Eagles. 


\subsubsection{Climate}

In Pend Oreille County, summers are warm or hot in most valleys and much cooler in the mountains. Winters are cold in the mountains. Valleys are colder than the lower slopes of the adjacent mountains because of the cold air drainage. Precipitation occurs in the mountains throughout the year, and a deep snowpack accumulates during winter. Snow melt usually supplies more water than can be used for agriculture in the project area. In the valleys summer precipitation falls during showers and thunderstorms. In winter, the average temperature is $27-28$ degrees $\mathrm{F}$ and the average daily minimum temperature is $20-21$ degrees F. In summer, the average temperature is 63 degrees $F$ and the average daily maximum temperature is 79 degrees $\mathrm{F}$. The total annual precipitation is about 27 inches. About 9-11 inches, or 30-40 percent, usually falls from April through September. Most of the crops growing seasons fall in this time frame. The average seasonal snowfall is about 62 inches at Boundry Dam and 70 inches at Newport.

\subsubsection{Soils}

Due to the importance of soils to wetland establishment and function, a brief description follows.

Dalkena fine sandy loam (39) 0-7 percent slopes. This very deep, moderately well drained soil is on terraces. It formed in glaciofluvial deposits over clayey glacial lake sediments. The native vegetation is mainly conifers, shrubs, forbs, and grasses. The average annual precipitation is $25-30$ inches, the average annual air temperature is about 44 degrees $\mathrm{F}$, the average growing season is $90-110$ days, and the average frost-free period is $75-105$ days.

Permeability is moderate to a depth of 30 inches in this Dalkena soil and slow below that depth. Available water capacity is high. The effective rooting depth is limited by a perched seasonal high water table at a depth of 2-3 feet from February through April. Runoff is slow, and the hazard of water erosion is slight. Douglas fir, ponderosa pine, and western larch are the main woodland species of this soil type.

Cusick silty loam (38): This very deep, somewhat poorly drained soil is in basins. It formed in fine textured glacial lake sediments. Slope is 0-3 percent. Native vegetation is mainly shrubs, forbs, and grasses. Average annual precipitation is $25-27$ inches, the average annual air temperature is about 44 degrees F, the average growing season (at 28 degrees) is 90-100 days, and the average frost-free period is 75-105 days.

Permeability is very slow in the Cusick soil and available water capacity is high. Effective rooting depth is limited by perched seasonal high water table within a depth of 2 feet from November through April. Runoff is very slow, and the hazard of erosion is slight.

\section{METHODS}

\subsection{General}

Habitat Evaluation Procedures (HEP) were applied to measure the baseline condition. HEP was the standard loss estimator in all hydropower loss statements submitted to the 
NPPC. BPA required its use on a project specific basis for increased detail and accuracy on projects accepted into the advance design phase.

The Bureau of Indian Affairs (BIA) Forestry Branch at the tribal headquarters provided color stereo aerial photographs. Habitat types were delineated onto mylar overlays, and then determination of area was established using a digital planimeter.

The permit process for work within wetlands can be extensive and the following agencies will be contacted before work begins U. S. Army Corps of Engineers and Washington Department of Fish and Wildlife.

KNRD fisheries personnel conducted a preliminary fisheries survey of Campbell's Slough using a backpack electroshocker, electroshocking boat, as well as a water quality survey using a Hydrolab Scout II.

BPA conducted a hazardous material survey as part of the NEPA process. Results are not reported here, but are on file in their Portland Office.

To properly recreate the riparian forest type, an undisturbed stand is desired as a model. We were fortunate in finding such an area immediately adjacent of the project site. The U. S. Forest Service owns this parcel and although it has received some level of grazing, it appeared to never have been farmed or logged. We took note of species composition, density and juxtaposition. This site was also used as the model for the "Flying Goose Ranch."

\subsection{Habitat Evaluation Procedure (HEP)}

The objective of the Habitat Evaluation Procedures conducted on the project site was to rate the quality of lands being considered for purchase and management as partial mitigation for Albeni Falls Dam. The product of the baseline survey will determine the number of "Habitat Units" $(1 \mathrm{H}$. U. $=1$ acre of optimum habitat, or e. g. 2 acres of habitat rated at 0.5 ) currently available for individual indicator species, and the amount that will become available with management. Indicator species were used to determine the habitat quality rating and available habitat units. They were Bald Eagle, Canada Goose, Muskrat, Black-capped Chickadee, Yellow Warbler and Mallard. Martin et al. (1988) also used Whitetailed deer. We chose not to use it due to its very wide ecological amplitude. The other species, being more dependent on specific habitats, are better indicators of habitat condition. Deer should respond positively to habitat management planned for implementation.

An interdisciplinary team was assembled to complete the baseline HEP procedure. A Habitat Evaluation Procedures Manual was created to aid the team in rating the quality of the habitat. This manual provided the team with Habitat Suitability Index (HSI) Models, which described life requisites for each indicator species. This enabled the team to derive a number value between 0.0-1.0 corresponding to the quality of the habitat (HSI score). The team conducted the site surveys and collected data on habitat type, quantity, quality and wildlife use under existing conditions at established sites (Figure 1).

For a full explanation of the HEP process on this project, including models, data collection and interpretation see Appendix A. 


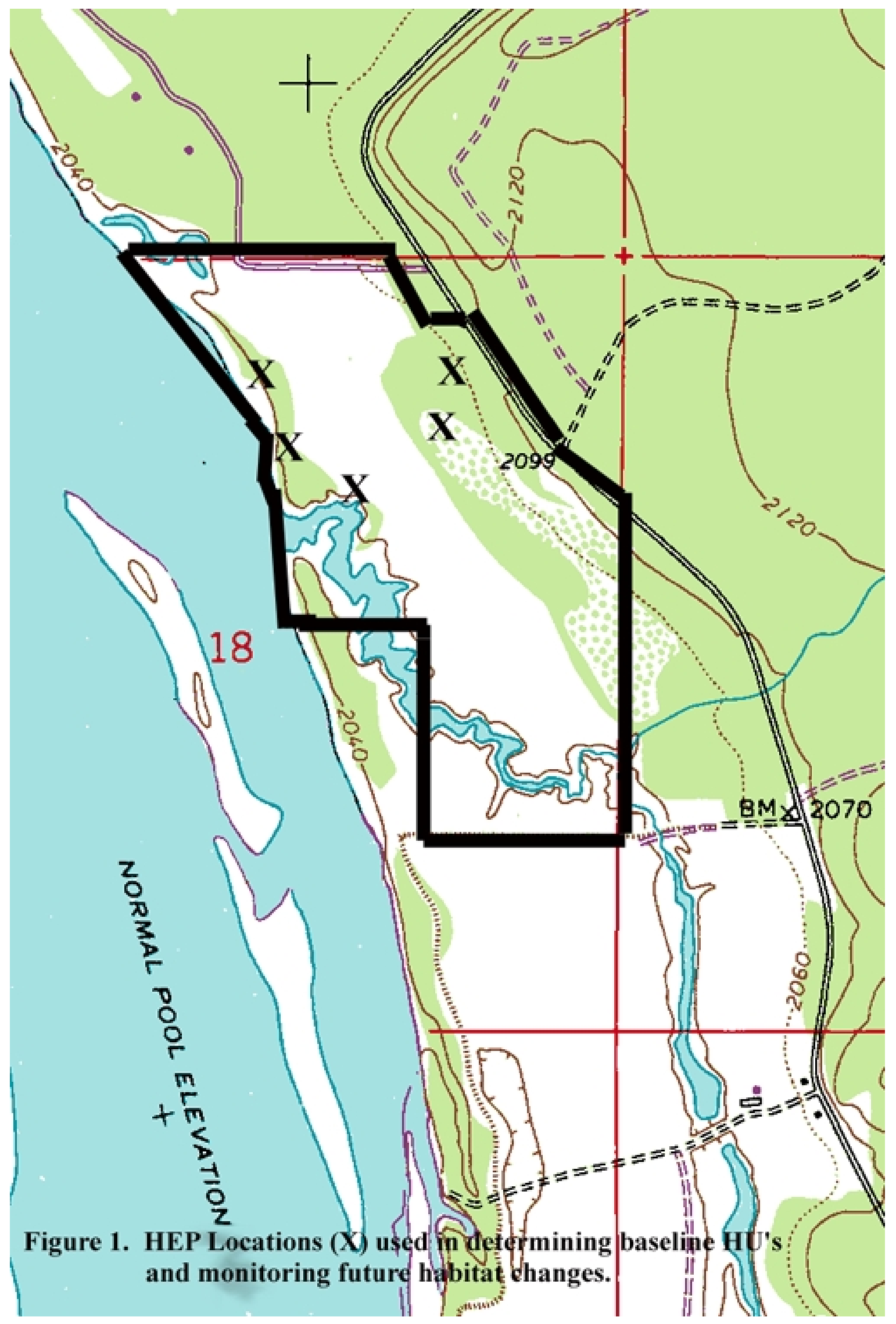




\subsection{Habitat Evaluation Procedures}

Following collection of field data, Habitat Suitability Indices (HSI) were calculated from models, and multiplied by acres of habitat type. The resulting Habitat Units are represented by indicator species. This is the baseline, or current, HU's for the project area. See Section 7.0 for a full explanation of HEP results, and identification of limiting factors that will be targeted under a management plan based on HEP results.

\subsection{Riparian Forest}

Results from the riparian forest showed lower stems/acre within the project as compared to the control or model forest site (Table 3).

Table 3. Stems/acre analysis compared between the model site (USFS) and the riparian forest within the project site.

\begin{tabular}{|c|c|c|c|c|}
\hline Site & $\begin{array}{l}\text { Dominant } \\
\text { Overstory }\end{array}$ & $\begin{array}{c}\text { Mean } \\
\text { Height (ft) }\end{array}$ & $\begin{array}{l}\text { Canopy } \\
\text { Closure }\end{array}$ & Stems/acre \\
\hline Dilling Addition & & & & \\
\hline $\operatorname{HEP} 2$ & cottonwood & 72 & $78 \%$ & 175 \\
\hline HEP 3 & mixed deciduous & 52 & $55 \%$ & 225 \\
\hline US Forest Service & & & & \\
\hline Mature & cottonwood & 78 & $98 \%$ & 300 \\
\hline Pole & cottonwood & 5 & $99 \%$ & 900 \\
\hline
\end{tabular}

\subsection{Upland Forest}

The BIA forestry department collected Upland forest information on tree volume and species composition. Data indicated a mixed species conifer forest dominated by small mature western red cedar (Table 4). Stocking levels were reported to be $70 \%$ small mature size trees and $30 \%$ pole size trees.

Table 4. Upland forest composition data complied for the Dilling Addition.

\begin{tabular}{llcc} 
Tree Species & & Volume $(\mathrm{mbf})$ \\
\cline { 1 - 1 } ponderosa pine & & 1.881 \\
lodgepole pine & & 1.422 \\
western larch & & 0.990 \\
western hemlock & & 1.000 \\
grand fir & & 14.094 \\
Douglas fir & & 7.938 \\
western red cedar & & 53.584 \\
Total & & $\mathbf{8 0 . 9 0 9}$
\end{tabular}




\subsection{Fisheries Data}

Species presence is based on information obtained from two 300 second shocking transects conducted April 20, 1998 in Campbell Slough of the Pend Oreille River (Table 5).

Table 5. Species occupying Campbell Slough based on an electrofishing sample conducted by the Kalispel Natural Resource Department and the Washington Department of Fish and Wildlife, April 20, 1998 in order from most to least abundant.

Common Name

brown bullhead

peamouth

largemouth bass

pumpkinseed

black crappie

yellow perch

northern pike minnow

tench

large scale sucker
Scientific Name

(Ictalurus nebulosus)

(Mylocheilus caurinus)

(Micropterus salmoides)

(Lepomis gibbosus)

(Pomoxis nigromaculatus)

(Perca flavescens)

(Ptychocheilus oregonensis)

(Tinca tinca)

(Catostomus macrocheilus)

\subsection{DISCUSSION}

The seven indicator species were chosen to gauge the current condition of the existing habitat, as well as to set goals for future improvement. The condition of the existing habitat was measured through the HEP process discussed earlier. In this section, discussion of each species and respective habitat management tasks is by habitat type. The HEP variables are used as a basis of management. However, also included are additional management techniques not included in the model that are important to the species, as well as to increase both habitat and wildlife diversity on the project.

Land acquisition is the first and most critical step in the management process. In 1997, the Tribe (with BPA funding) bought the 164-acre site from the landowner. Following acquisition, permanent management practices will be implemented. Numerous site visits, observations of wildlife, the HEP process and wetlands delineation were all used to formulate objectives. These objectives will be met by performing a series of tasks. The order or level of implementing the tasks was arranged by a variety of factors such as ease of implementation, costs, permit constraints and urgency. At either end of the spectrum, for example, is cessation of cattle grazing on 106 acres and restoration of the riparian forest. The former is most urgent, due to its severe impact to the existing riparian forest and shoreline. It is clear in that by not doing something (grazing cattle) we allow the forest, shoreline, wetlands and grassy field to begin recovery. Conversely, riparian forest restoration will be a very proactive, money and time-dependent endeavor. 


\subsection{Implementation}

\section{Level I. Objectives and Tasks}

\section{Objective 1.1 Baseline Inventory}

Baseline wildlife surveys will be conducted by target species guild. For example, Bald Eagle winter use will be assessed by total counts from November to April. The entire area will be surveyed using binoculars and spotting scope. Spring pair and lone drake counts will measure Waterfowl response on the project site. Breeding bird populations (including Black-capped Chickadee and Yellow Warbler) will be determined initially, and monitored through the project, using line transect and point methods. These methods, as well as those developed by the region will continue through the monitoring phases (Level IV Task IV.1).

\section{Objective 1.2 Cattle Grazing}

\section{Task I.2.1 Cessatation}

All grazing was stopped at time of acquisition. Degraded and declining banks and riparian forest is all a result of unrestricted season-long grazing for many years. Grazing may be used in the future on a limited basis to meet specific goals for wildlife, e.g. to open up dense stands of cattails, or to prepare for planting of woody vegetation. Grazing will not occur near river shore, or in any habitat type dominated by aspen or black cottonwood. The latter is preferred that cattle seek it out first, and even eat fallen leaves (Sedgewick and Knopf 1991).

\section{Task I.2.2 Modified Use}

If cattle grazing is used in the future, electric fence will be used, at the lessees expense, to contain the livestock. No new barbed wire fence will be established. Old interior fences will be removed. Perimeter fences will be repaired and retained. Barbed wire is a potential hazard to birds and deer, and to some extent moose, which are locally increasing.

\section{Objective I.3 Weed Control}

An undesirable plant list for the property was collected and set by the Pend Oreille County Noxious Weed Control Board (Sorby pers. comm. 1998). Class A Noxious Weeds and Class B-Designate Noxious Weeds have mandatory control requirements. However, none were found on project site. A number of Classes B and C Noxious Weeds, as well as non-classified "undesirable" plant species were found. Control is not required, but recommended (Sorby pers. Comm. 1998). 


\section{Task I.3.1 Control and Maintenance}

Most weeds occur as a result of disturbance resulting in much bare ground due to intensive, season-long grazing. With removal or reduction of grazing, weeds such as bull thistle and mullein are expected to disappear as grass competition increases. Sorby pers. comm. (1998) provided a set of recommendations. We will work closely with the County Weed Board in implementing these recommendations. Following control during implementation, regular spot maintenance control will occur during the O\&M phase.

\section{Level II}

These objectives were identified primarily through the HEP process. They were believed to be the limiting factors to target species of wildlife and so are priority implementation items and include the following with target species in parenthesis (Appendix A):

- $\quad$ Increased perch size (Bald Eagle)

- $\quad$ Increased tree density in deciduous forest (Black-capped Chickadee/Bald Eagle)

- $\quad$ Revegetation of river shoreline (Canada Goose, Mallard and muskrat)

- $\quad$ Restoration of wetland shrubs (Yellow Warbler, Mallard)

- $\quad$ Increased grass nesting cover (Mallard)

- $\quad$ Manage pastures for brooding habitat (Canada Goose)

- $\quad$ Seasonally flooded wetland enhancement (Mallard and muskrat)

\section{Objective II.1 Upland Forest Management}

\section{TaskII.1.1 Forest Health}

With Bureau of Indian Affairs Forestry Division assistance, accepted techniques will be applied to maintain healthy tree stands. The mixed coniferous-deciduous forest was logged in approximately 1985. This logging removed the largest and/or more superior sawlog trees. Timber stand improvements will be implemented on an as needed basis to maintain the health and viability of the stand.

\section{Objective II.2 Increased Deciduous Tree Density}

\section{Task II.2.1 Aspen Release}

Within the mixed forest and Task II.1.1 described above, we will encourage aspen release. This will be done by removing competing vegetation, especially conifer, from within and near aspen stands. Aspen prefers full sunlight and higher moisture than conifers. Stands should sucker well and expand following removal of competition, and minor root disturbance. 


\section{Task II.2.2 Cottonwood Enhancement}

Within the riparian forest, two techniques will be employed to increase deciduous tree density. The primary species here is black cottonwood. Restriction/removal of cattle grazing has been discussed earlier. An indication of cottonwood sprouting potential and cattle impacts were evident through 1996.

Following the restriction of livestock grazing, planting of cuttings will commence. A low density ( 200 stems/acre) planting will help speed both increased density and mean height following many years of grazing impacts. The planting density was chosen to speed, and to give some assurances that, the recovery will approach 900 stems/acre in an undisturbed young stand, versus the current level of about 200 stems/acre.

\section{Level III}

This third level of effort includes the most detailed and scaled items of implementation. Engineering, costs and permitting are all more complex. However, the rewards are greatest of all, due to the conversion of the lowest valued cover type, tame pasture, to two of the highest valued types, riparian forest and emergent palustrine wetland. The acreage involved is also extensive and represents about one-half of all project lands. The primary constraint is agency permitting, a process of unknown length. Time to maturation to full wildlife benefits in restored forest will also be a significant factor.

\section{Objective III.1 Riparian Forest Restoration}

Extensive losses of forested wetlands were caused by the Albeni Falls Dam project. Bald Eagles are dependent on this habitat for nesting, roosting, and perching. Lost Bald Eagle habitat units were greatest of all target species on Kalispel Reservation.

We propose to restore damaged areas to black cottonwood-dominated forest, with an understory of willow and red-osier dogwood to be planted simultaneously. Local stock will be collected and rooted prior to planting. This will be done to increase survival, as the higher, drier interior of the pasture is to be planted. During the summer prior to planting, a certain amount of acres will be fallowed over each of 3 years to control weeds. The plantings will occur in the following spring.

\section{Task III.1.2 Pole Cuttings}

For best results, the guidelines to be followed for planting unrooted cuttings were outlined by Hoag and others (undated) for planting riparian areas in Idaho, and Swenson (1988) for New Mexico with project specific needs included.

- In year prior to planting, weaken pasture grass competition by intense grazing, herbicide or tillage.

- Collect cuttings in dormant season, remove all side branches, seal the top if necessary, and store in cooler at 3-6 C until planting.

- Cuttings should be a minimum of $1.5-3$ " dbh - larger is better. 
- Length of cuttings should be great enough to reach mid-summer water table (about 3' deep on project), 3-10 long is recommended.

- Soak cuttings in water 1-10 days prior to planting in April.

- Planting depth should be $1 / 2-2 / 3$ length of cutting for best soil-stem contact.

- For ease and greatest efficiency of planting, a tractor with an auger or steel rod should be used to create a hole of sufficient size and depth.

- Planting supplements did not increase survival or performance (removal of competition was not addressed).

- Back fill the holes carefully to avoid air pockets.

- Remove all buds and stems as they grow from the lower two-thirds of the pole.

- Only $1 / 8$ to $1 / 4$ of the non-wetland pasture acreage will be planted. Randomized group plantings will be made with openings between to maximize edge.

- Control competition.

\section{Task III.13 Rooted Cuttings}

Plant materials will be acquired through area native plant nurseries.

\section{Task III.1.4 Irrigation and Costs}

\section{Objective III.2 Pasture Management}

\section{Task III.2.1 Manage for goose brood pastures}

In order to assist mitigation for Canada goose habitat units, high quality brood habitat needs to be created. Brood habitat may well be more restrictive to populations than nesting sites, as evidenced by long travel distances to brood areas following hatching (Ball et. al., 1981). Mackey and others (1987) found that grazing broods generally remained within 30 meters of the security of water. Management of brood pasture will entail keeping grass lengths at 4" or less, during the brood season (April-July 15). Pastures should be managed out to $100 \mathrm{~m}$ from the water edge to provide visual security. Based on the above parameters, and planned wetland expansion, there is an estimated 20 acres of brood pasture that could be created.

A top seeding of Camas (Camassia quamash) will occur. Once very common, and a preferred cultural and food item of the Tribe, it is now much reduced over its range. Improper livestock grazing quickly removes it from the flora. It is still common on the reservation where livestock grazing is less intense. Seed will be collected here for use on project.

Following wild pasture establishment, annual mowing or haying will occur following seed set by camas. Purpose is to prevent invasion by undesired species, maintain vigor of grasses and open nature desired by flightless broods of Canada geese. The KAE tractor will be employed for an agreed upon lease price. 


\section{Objective III.3 Wetland Management}

\section{Task III.3.1 Manage wetlands for diversity and quality}

Wetland areas were determined using ground truthing and mapping (Figure 2). Areas of potential wetland development have been identified along the slough margins within the old creek channel meanders. Wetland developments will include various uses of deleveling and small non-controlled check dams to maximize diversity and quality within the project area.

\section{Level IV}

Long term analysis of results and assurance of benefits is essential, yet often ignored or improperly funded in mitigation projects. Kusler and Kentula (1990) in their database noted that monitoring of mitigation projects has been uncommon so that the potential information gained to improve future projects is not being accrued.

\section{Objective IV.1 Monitoring and Evaluation}

The Power Council, Bonneville, Columbia Basin Fish and Wildlife Authority and Kalispel Tribe need to monitor and evaluate the effectiveness of the wildlife program. Assessment of conditions before and after habitat enhancement is essential for auditing purposes.

Reference data concerning changes relative to the baseline condition (Objective I.1) will be continued throughout the life of the project. In addition, habitat and vegetation responses will be measured and correlated with trends in wildlife populations. Permanent plots in each habitat type will be established and measured over time.

Selecting and permanently marking each HEP site for each vegetation type will aid in monitoring habitat changes over time. Parameters to be measured include HEP variables by target species as well as species of trees, shrubs, forbs and grasses present, height, density and distribution of these species, percent tree and shrub canopy cover, acres of wetlands and riparian forest successfully established. Water table levels will be monitored and correlation with vegetation development. At year 10, a HEP will be conducted using the target species.

Wildlife populations will be monitored by conducting a winter survey to estimate the number of Bald Eagles and deer, spring pair counts to determine the number of waterfowl, line transect song bird estimates, and other standard methods for estimating animal populations. The results of these efforts will then be correlated with the follow-up HEP.

Annual photographic documentation will occur at each HEP site and at each planting site to record vegetation development.

The mitigation project offers a unique opportunity to rectify current deficiencies in method knowledge. In the creation of a wetlands restoration database, Ischinger and Schneller-McDonald (1988) looked at study length duration. Based on 79 records, they found the majority of records concerned with one year, or less, of monitoring and evaluation efforts. Few studies were sufficient to provide useful knowledge as to long term relationships and success. 

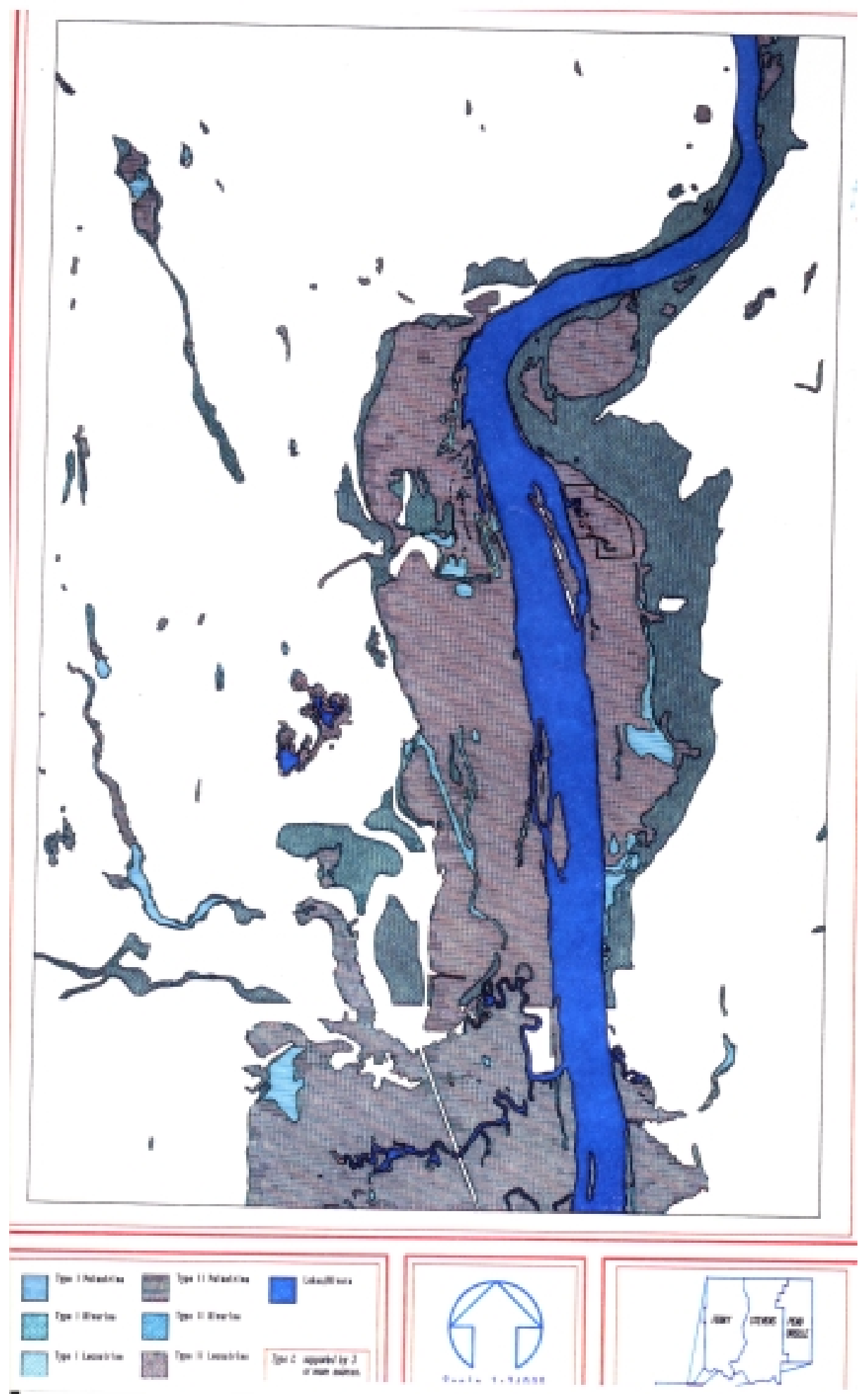

Figure 2. Wetlands inventory map of Pend Oreille County and project site. 


\section{Objective IV.2 Operations and Maintenance}

The category, like monitoring and evaluation, seemed mostly ignored in the literature. The only way to assure long term success is to apply them both for a term equal to the life of the hydro project to which they are assigned. Adaptive management cannot occur unless both are applied.

Funding for a .2 FTE manager and a .2 FTE biologist, plus equipment costs and overhead has been included in Section 4.2.

\subsection{BUDGET}

Project costs are incorporated into and a part of Goose budget and were figured using a variety of methods. An extensive literature review, many telephone conversations to resource personnel, equipment and nursery estimates, and personnel costs at KTOI and local operators were all used. Costs are in 1998 dollars (Table 6). Discussion of project costs by objective/task and a funding mechanism as follows.

\subsubsection{Project Costs}

Objective I.1

Baseline Inventory

A four-tenths "full-time equivalent" (FTE) personnel is needed throughout the project. This will consist of a technician, and a biologist. Together they will be responsible for supervising, coordinating, implementing, monitoring, and maintaining the project.

$\begin{array}{llll}.4 \quad \text { FTE } & @ & \$ 35,600 & \$ 14,200 \\ \text { Benefits } & @ & 35 \% & \$ 4,900 \\ \text { Mileage, equipment, supplies } & \$ 3,500 \\ \text { Overhead } & @ \quad 20 \% & \$ 3,800 \\ & \text { Annual subtotal } & \$ 26,400\end{array}$

Objective I.2 Weed Control

Initial Control for the first three years $\$ \$ 2,000$

$\begin{array}{ll}\text { Annual Maintenance } & \$ 500\end{array}$

Objective II.1 Upland Forest Management

No cost as done through BIA

Oversight/planning

$\$ 500$

Objective II.2

Supplemental planting

Aspen Release

Objective III.1

Reforestation
Increased Deciduous Tree Density

40 acres@\$200/acre

$\$ 8,000$

15 acres@\$250/acre

$\$ 3,750$

Riparian Forest Restoration

20 acres@\$450/acre
$\$ 9,000$ 
Objective III.2

Includes tractor, disc, drill, auger

Pasture Management

Objective IV.1 Monitoring and Evaluation

(Included in Baseline Objective. No net \$ increase to project)

$\$ 2,500$

Objectives IV.2

Operations and Maintenance

Included in Objective IV. 1.

$\$ 17,295$

\subsubsection{Total project costs over outyears}

Table 6. Objectives and costs per year to implement restoration, enhancement and O\&M activities on the project.

\begin{tabular}{|c|c|c|c|c|c|}
\hline Objective & 2000 & 2001 & 2002 & 2003 & $2004+$ \\
\hline I.1 Baseline & 26,400 & - & - & & 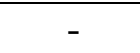 \\
\hline I. 2 Weed control & 2,000 & 2,000 & 2,000 & 500 & 500 \\
\hline II.1 Upland forest & 500 & - & - & - & - \\
\hline II. 2 Deciduous tree density & 4,000 & 4,000 & 3,750 & - & - \\
\hline III.1 Riparian forest restore & 3,000 & 3,000 & 3,000 & - & - \\
\hline $\begin{array}{l}\text { III.2 Pasture management } \\
\text { IV.1 M \& E }\end{array}$ & 2,500 & 2,500 & 2,500 & 1,000 & 1,000 \\
\hline IV.2 O \& M & - & 27,500 & 28,600 & 29,700 & 31,000 \\
\hline Total Cost & 38,400 & 39,000 & 39,850 & 31,200 & 32,500 \\
\hline
\end{tabular}




\subsection{SOURCES}

\subsection{Literature}

Baird, K. 1989. High quality restoration of riparian ecosystems. Restoration and Management Notes 7(2) 60-64.

Ball, I. J.; Bowhay, E. L. and Yocum, C. F. 1981. Ecology and management of the western Canada Goose in Washington. Wash. Dept. Game Biol. Bull No. 17.

Brinson, M. M.; Swift, B. L.; Plantico, R. C.; and Barclay, J. S. 1981. Riparian ecosystems: Their ecology and status. USFWS. RFW/OBS-81-17. 155 pp.

Burger, G. V. and Webster, C. G. 1964. Instant nesting habitat. Chapter in Linduska, J. P. ed. Waterfowl Tomorrow USDI Fish and Wildlife Service, Washington D. C.

Canning, D. J. and Stevens, M. 1989. Wetlands of Washington: A Resource Characterization. Land and Wetland Resources Subcommittee, Environment 2010 Advisory Committee, Wash Dept. Ecology, Olympia.

Carothers, S. W.; Mills, G. S. and Johnson, R. R. 1990. The creation and restoration of riparian habitat in southwestern arid and semi-arid regions. Pgs. 351-366 in Kusler, J. A. and Kentula, M. R. eds. Wetland Creation and Restoration: The Status of the Science. Island Press, Washington, D. C.

Castelle, A. J.; Conolly, C.; Emers, M.; Metz, E. D.;Meyer, S.; Witter, M.; Mauermann, S.; Bently, M.; Sheldon, D. and Dole, D. 1992. Wetland replacement ratios: defining equivalency. Adolfson and Associates, Inc., for Shorelands and Coastal Zone Management Program, Wash Dept. Ecology, Olympia, Publ. No. 92-08.

Cordery-Cotler, Flying Goose Ranch, Cusick, Washington Environmental Survey. Report from CH2M Hill to Bonneville Power Administration, Portland, OR. Dec. 1991. 17 pp.

Hoag, J.C.; Young, G. L.; and Gibbs, J. L. undated. Planting techniques for vegetating riparian areas from the Aberdeen Plant Materials Center. USDA-SCS, Aberdeen, ID.

Ischinger, L. S. and Schneller-McDonald, K. 1988. Wetland Restoration and creation in the West: What do we really know? Pp. 29-42 in Mutz, K. M.; Cooper, D. L.; Scott, M. L. and Miller, L. K. tech. eds. Restoration, creation and management of wetlands and riparian ecosystems in the American West. Society of Wetland Scientists, Denver, $\mathrm{CO}$.

Knopf, F. L. 1988. Riparian wildlife habitats: more, worth less and under invasion. Pp. 20-22 in Mutz, K. M.; Cooper, D. L.; Scott, M. L. and Miller, L. K. tech. eds. Restoration, creation and management of wetland and riparian ecosystems in the American West. Society of Wetland Scientist, Denver, CO. 
Kusler, J. A. and Kentula, M. E. (eds.). 1990. Wetland Creation and Restoration: The Status of the Science. Island Press, Washington, D. C.

Lea, R. and Frederick, D. J. Bottomland hardwood restoration in the southeast-a perspective. Journal of land and water conservation. Sept/Oct. 1992.

Mackey, D. L.; Gregory, S. K.; and Matthews, Jr. W. C. 1987. Impacts of water levels on breeding Canada geese and methods for mitigation and management in the southern Flathead Valley, Montana. Bonneville Power Project \#83-2. Portland, OR.

Martin, R. C.; Hensen, H. J. and Mueleman, G. A. 1988. Albeni Falls wildlife protection, mitigation and enhancement plan. BPA Project \#87-43. Portland, OR.

Merker, C. and Scholz, A. 1990. Kalispel Tribe of Indians Wildlife mitigation and restoration for Albeni Falls Dam. Upper Col. United Tribes Fisheries Center, EWU, Cheney, WA.

Richter, B. 1992. Hydrologic monitoring manual. The Nature Conservancy, Boulder, CO.

Schemnitz, S. D. ed. Wildlife Management Techniques Manual. The Wildlife Society, WA.

Sedgewick, J. A. and Knopf, F. L. 1991. Prescribed grazing as a secondary impact in a western riparian floodplain. Journal of Range Management. 44(4): 369-373.

Sorby, S. L.; Larson, G. and Ceretto, P. 1992. Flying Goose Ranch Mitigation Project undesirable plant survey for the Bonneville Power Administration. Pend Oreille County Weed Board, Newport, WA. BPA contract \#DE-BI-79-92BP75859.

Swenson, E. A. 1988. Progress in the understanding of how to reestablish plants in New Mexico. In Murtz, K. M. Cooper, D. L.; Scott, M. L. and Miller, L. K. tech. eds. Restoration, creation and management of wetland and riparian ecosystems in the American West. Society of Wetland Scientist, Denver, CO. 


\section{APPENDIX A}

Habitat Evaluation Procedures for the

Pend Oreille Wetlands Wildlife

Mitigation Project-Adjacent to Flying Goose Ranch

By

Ray Entz

Wildlife Program Manager

Kalispel Natural Resource Department 


\begin{abstract}
The Habitat Evaluation Procedure (HEP) was used to determine baseline information on habitat suitability for the target species using Habitat Suitability Index (HSI) Models. These HSI species models consisted of the bald eagle- wintering and breeding, black-capped Chickadee, Canada goose, muskrat, and yellow warbler. A HEP team was assembled with persons from several different agencies. The team consisted of the following persons and agencies: Ray Entz, KNRD Wildlife Program Manager; Bryon Holt, USFWS biologist; Peter Paquet, NPPC wildlife biologist; Sean Ebnet, Pend Oreille County PUD\#1 consultant; and Phil Havens, BPA COTR. Using an ocular measurement method the HSI was conducted as a group with the HSI values for each variable being the agreed upon team value. The HSI models were determined to be as follows: bald eagle breeding- 0.68 in the deciduous forest cover type and 0.63 in the coniferous forest cover type, bald eagle wintering- 0.6 in the deciduous forest cover type, Canada goose- 0.5 in the riparian herbaceous cover type, muskrat-0.96 in the herbaceous wetlands cover type, yellow warbler-0.68 in the deciduous shrub/deciduous shrub wetland cover types, and mallard- 0.3 in pasture type. These values are based on a 0.0-1.0 scale where 1.0 is the optimum value for habitat in a given cover type. These values were within expected ranges as current land use has degraded the habitat within the property borders.
\end{abstract}

\title{
INTRODUCTION
}

Habitat Evaluation Procedure (HEP) is used extensively in today's fish and wildlife biological sciences to determine habitat losses and/or benefits to the habitat after construction of a facility, or enhancement or restoration of habitat. HEP utilizes habitat suitability index (HSI) models for target species found within certain cover types. An example of this would be the muskrat HSI model for the herbaceous wetland cover type.

In 1987, the Albeni Falls work group collected baseline HEP data on the Pend Oreille River Area. During this survey the Albeni Falls work group provided HEP data for eight target species representative of area cover types that were adversely effected by the construction of the Albeni Falls Dam. Baseline data collected by the Pend Oreille wetlands work group was accomplished using the same target species as used by the Albeni Falls work group excluding the white-tailed deer model. It was decided that the other HSI models adequately included the habitat and cover types.

The Pend Oreille work group consisted of seven members, each of which was picked for expertise in a certain area and/or personal or agency interest. The work group consisted of the following individuals and agencies: Ray Entz, KNRD Wildlife Program Manager; Bryon Holt, USFWS biologist; Peter Paquet, NPPC wildlife biologist; Sean Ebnet, Pend Oreille County PUD\#1 consultant; and Phil Havens, BPA COTR.

The goal of this project is to obtain baseline data to determine current levels of habitat suitability for the project property and to present a representation of the benefits of restoration on the current habitat. 


\section{METHODS}

Habitat types were mapped from color photographs, then ground truthed. Habitat type area was computed using a digital planimeter.

The HSI models for the Canada goose, breeding Bald Eagle and wintering Bald Eagle were modified from those used by the Albeni Falls work group. The black-capped Chickadee, yellow warbler and the muskrat HSI models were acquired from Bob Martin, IDFG wildlife biologist and head of the Albeni Falls work group. Models and field data forms can be found at the end of the report. The HSI models were modified to a histogram format for ease in use during the ocular measurement method. These models were forwarded to work group members for review and comments. It was determined that the ocular measurement method is as accurate as actual direct measurements (P. Ashley, WDW, pers. comm.).

Each target species were selected for their associations with specific cover types. Each HIS model consists of several variables with each variable being split into several categories. Each category was assigned a value between 0.0 and 1.0 The scores for each variable was then calculated using the HSI equation(s) for each model and given final HSI score (Table 1). The final score is criteria for which habitat suitability is determined. The habitat suitability is based upon a numerical range between 0.0 and 1.0, where 1.0 is the optimal suitability for a given cover type.

\section{RESULTS}

Table 1 shows habitat type classification and acreage used to figure Habitat Units for the target species.

Table 2 is a summary of the results of HEP including HIS scores by species and habitat, and total baseline Habitat Units on the site.

Table 1. Pend Oreille Wetlands II Mitigation Project habitat types and acreage. The total acreage is higher than 164 due to the inclusion of land below the ordinary high water mark.

\begin{tabular}{lcc} 
Habitat Type & & Acreage \\
\cline { 1 - 1 } Project Area (including beach and sloughs to & & \\
Riparian Deciduous Forest & & 18.1 \\
Upland Coniferous Forest & & 17.4 \\
Open Water & 8.1 \\
Herbaceous Emergent Wetland & 5.7 \\
Scrub-Shrub Wetland & 14.9 \\
Deciduous Forest/Scrub-Shrub & 18.4 \\
Shoreline & & 66.1
\end{tabular}


Table 2. Baseline Habitat Evaluation Procedure for the 164-Acre addition to the Pend Oreille Wetlands project.

\begin{tabular}{|c|c|c|c|c|c|c|}
\hline HEP Cover Species & HEP Variable & $\begin{array}{l}\text { Var. } \\
\text { Score }\end{array}$ & $\begin{array}{c}\text { HSI } \\
\text { Equation }\end{array}$ & $\begin{array}{c}\text { HSI } \\
\text { Score }\end{array}$ & Acres & HU's \\
\hline Bald Eagle (breeding) & $\overline{\text { V1 - Food }}$ & 1 & $(\mathrm{~V} 2 * \mathrm{~V} 3 * \mathrm{~V} 4)^{1 / 3}$ & 0.69 & 18.8 & 12.9 \\
\hline \multirow[t]{3}{*}{ Coniferous Cover } & V2 - Nest & 0.4 & & & & \\
\hline & V3 - Dist. to $\mathrm{H} 2 \mathrm{O}$ & 1 & & & & \\
\hline & V4 - Human Distr. & 0.8 & & & & \\
\hline Bald Eagle (breeding) & V1 - Food & 1 & $(\mathrm{~V} 2 * \mathrm{~V} 3 * \mathrm{~V} 4)^{1 / 3}$ & 0.95 & 40.1 & 38.1 \\
\hline \multirow[t]{3}{*}{ Deciduous Cover } & V2 - Nest & 0.9 & & & & \\
\hline & V3 - Dist. to $\mathrm{H} 2 \mathrm{O}$ & 1 & & & & \\
\hline & V4 - Human Distr. & 0.95 & & & & \\
\hline Bald Eagle (wintering) & V1 - Food & 1 & {$\left[(\mathrm{~V} 1)^{2} * \mathrm{~V} 2\right]^{1 / 3}$} & 0.59 & 18.8 & 11.1 \\
\hline \multirow[t]{3}{*}{ Coniferous Cover } & V2 - Perch & 0.2 & & & & \\
\hline & V3 - Dist. to $\mathrm{H} 2 \mathrm{O}$ & 1 & & & & \\
\hline & V4 - Human Distr. & 0.8 & & & & \\
\hline Bald Eagle (wintering) & V1 - Food & 1 & {$\left[(\mathrm{~V} 1)^{2 *} * \mathrm{~V} 2\right]^{1 / 3}$} & 0.93 & 40.1 & 37.3 \\
\hline \multirow[t]{3}{*}{ Deciduous Cover } & V2 - Perch & 0.8 & & & & \\
\hline & V3 - Dist. to $\mathrm{H} 2 \mathrm{O}$ & 1 & & & & \\
\hline & V4 - Human Distr. & 0.8 & & & & \\
\hline Black-capped Chickadee & V1 -\% Canopy Closure & 0.75 & $(\mathrm{~V} 1 * \mathrm{~V} 2)^{1 / 2}$ or $\mathrm{V} 3$ & 0.53 & 40.1 & 21.3 \\
\hline \multirow[t]{2}{*}{ Deciduous Forested Wetlands } & V2 - Avg. Tree Height & 0.97 & & & & \\
\hline & V3 - No. Snags/acre & 0.53 & & & & \\
\hline Yellow Warbler & V1 - \% Shrub Cover & 0.42 & $(\mathrm{~V} 1 * \mathrm{~V} 2 * \mathrm{~V} 3)^{1 / 2}$ & 0.38 & 20.6 & 7.9 \\
\hline \multirow[t]{2}{*}{ Scrub-Shrub Wetlands } & V2 - Avg. Shrub Height & 0.97 & & & & \\
\hline & V3 - \% Wetland Obl. & 0.37 & & & & \\
\hline \multirow[t]{3}{*}{ Canada Goose } & V1 - Island Nesting Habitat & 0.9 & {$[(\mathrm{~V} 1+\mathrm{V} 2) * \mathrm{~V} 3]^{1 / 2}$} & 0.94 & 39.9 & 37.3 \\
\hline & V2 - Shoreline Nesting & 0.35 & & & & \\
\hline & V3 - Brood Rearing Habitat & 0.7 & & & & \\
\hline \multirow[t]{3}{*}{ Mallard } & V1 - Wetland Type & 0.5 & Lowest Value & 0.50 & 106 & 53.0 \\
\hline & V2 - Nesting Cover & 0.6 & & & & \\
\hline & V3 - Shoreline Cover & 0.5 & & & & \\
\hline \multirow[t]{3}{*}{ Muskrat } & V1 - \% Cover & 0.3 & $(\mathrm{~V} 1 * \mathrm{~V} 2)^{1 / 2}$ or & 0.17 & 35.8 & 6.2 \\
\hline & $\mathrm{V} 2-\%$ of Year w/ $\mathrm{H} 2 \mathrm{O}$ & 1 & $(\mathrm{~V} 1 * \mathrm{~V} 3)^{1 / 2}$ & & & \\
\hline & V3 - \% Preferred Veg. & 0.1 & Lowest Value & & & \\
\hline Total & & & & & & 225.0 \\
\hline
\end{tabular}

